\title{
ANEMOPHILOUS FUNGI IN INTENSIVE CARE SECTORS OF A PUBLIC HOSPITAL IN THE NORTH OF PIAUÍ, BRAZIL
}

\author{
FUNGOS ANEMÓFILOS EM SETORES DE CUIDADOS INTENSIVOS DE UM HOSPITAL PÚBLICO NO NORTE DO PIAUÍ, BRASIL
}

PEREIRA, Darkcélia Barros ${ }^{1}$, CRUZ, Mateus Oliveira da ${ }^{1}$, ALVES, Maria Helena ${ }^{1}$

1 Universidade Federal do Piauí, Parnaíba, Brazil.

\begin{abstract}
The knowledge of fungi present in the air of hospital environments is extremely important for the detection and prevention of many diseases that can affect patients and professionals who attend such places. The aim of the present study was to assess the presence of anemophilous fungi in a public hospital localized in Parnaíba city, State of Piauí, Brazil. The methodology used was the exposure of Petri dishes containing Agar Martin culture medium in three sectors: Red room, Adult ICU and Neonatal ICU. The subsequent identification of the isolated fungi was by morphological analysis of the macro and microstructures of the fungi. It was found the 222 filamentous fungi colony contemplating eight taxa: Aspergillus fumigatus, A. oryzae, A. niger, Curvularia brachysphora, Geotrichum candidum, Ochroconis mirabilis, Penicillium citrinum and Rhizopus oryzae. The number of Colony Formation Units (CFUs) differed between sectors with the Red room having the highest number of CFUs (164) followed by Adult ICU and Neonatal ICU with 48 and 10 CFUs, respectively. The most frequent taxa were Aspergillus oryzae, A. niger and Rhizopus oryzae, with Aspergillus niger being the most prevalent taxon in almost all collects. All fungi, except Aspergillus oryzae, reported here have historic as pathogen for humans. These results serve as a warning for the prevention of nosocomial infections and for a greater hygiene profile in these environments.
\end{abstract}

Keywords: Fungal aerobiotic. Pathogenic fungi. Fungal propagules.

\section{INTRODUCTION}

Fungi are microorganisms endowed with unique characteristics that separate them from other groups of organisms on the planet. Among fungal microorganisms, some are capable of causing diseases to humans, being the objective of medical mycological study ${ }^{1,2,3}$. Still in 2017, estimated data registered more than 1.5 million deaths from fungal diseases, and more than one billion people in the globe affected by these diseases. High-risk fungal infections are acquired as a consequence of other diseases, due to the low immunity of the patients. Even though most fungal deaths can be avoided, fungal diseases have been neglected by public health authorities ${ }^{4}$.

The fungus that are in the atmospheric air are known like anemophilous fungi, with air being the common environment for the dispersion of these microorganisms which can propagate their spores through the wind $d^{5,6,7,8}$. The inhaled of spores found in the air are considered the main responsible for infectious diseases like systemic mycoses, respiratory tract infections, otitis, urinary infections, eye infections and mucosal irritations. As these microorganisms are abundantly dispersed in the environment, the types of pathologies cited are alert to humans ${ }^{9,10}$.

Knowledge about the presence of these kind of organism in the environment through it is isolation and identification, is important both for the prevention of many allergic diseases and mycoses and for the diagnosis of their pathological agent ${ }^{11,12}$.

Correspondência: ALVES, Maria Helena

e-mail:malves@ufpi.edu.br

Recebido: 26 fev 2020

Aprovado: 07 abr 2020
Lanzerstorfer et al. ${ }^{13}$ point out that anemophilous fungi have been a problem in hospital settings. Many species of filamentous fungal isolated from hospital air have been shown to be able to produce toxins, thus posing a risk to people working in these environments and specially to debilitated patients ${ }^{14}$. Many cases of nosocomial infections have been related to fungi, considering opportunistic species ${ }^{15,16}$. Studies like Oliveira et al. ${ }^{17}$ demonstrate that intensive care sectors require more attention due to the clinical condition of accommodated patients.

Given the scarcity of work on anemophilous fungi in a hospital environment in the state of Piauí and the concern with air quality of environments where high-intensity clinical treatments are performed, it was observed the need to carry out the study in order to verify the incidence of anemophilous fungi in a public health institution in Parnaíba, Piauí, Brazil.

\section{MATERIAL AND METHODS}

The work was carried out in three intensive care sectors of the State Hospital Dirceu Arcoverde - HEDA, in the city of Parnaíba, Piauí, Brazil, being: Red room, Adult ICU and Neonatal ICU. These sectors were chosen because are environments frequented by patients with critical clinical status. The fungal propagules were collected in the period from February to April 2018 in the morning, after cleaning the environment, following the air exposure method 
(environmental dust), using Petri dishes containing Martin culture medium $^{18}$, a specific for fungal growth.

The Petri dishes were exposed to the air for 10 minutes at a height of 1.5 meters above the ground and later transported to the laboratory where they were conditioned for 7 to 14 days or until the formation of Colony Formation Units (UFCs) at room temperature $\left(28^{\circ} \mathrm{C} \pm 2^{\circ} \mathrm{C}\right)^{19}$. Each collect was carried out in triplicate for each sector. The entire laboratory process was developed at the Mycology Laboratory (LABMIC) of Biological Sciences at the Federal University of Piauí, Campus Ministro Reis Velloso, where the development of CFUs was monitored daily by 8 days, which, after growth, were isolated in a specific medium (Agar Czapeck, Malt Extract Agar or Potato Dextrose Agar).

The Identification was made through the observation of macromorphological characteristics, such as color, texture, consistency, observing the front and back of colonies developed ${ }^{19}$. For the micromorphological identification, microcultures were performed and the slides were verified with the aid of the lactophenol blue dye for a better visualization of the fungal structures to the optical microscope following the methodology of Riddel ${ }^{20}$ using Potato Dextrose Agar (PDA) medium. Afterwards, the morphology was compared to the specialized taxonomic literature: Ellis ${ }^{21}$, Lacaz $^{19}$, Klich and $\mathrm{Pitt}^{22}$ and Shi et al ${ }^{23}$.

\section{RESULTS AND DISCUSSION}

Through the exposure of Petri dishes in the three sectors of the hospital, 222 fungal colonies were obtained and from those identified eight taxa (Fig. 1) with different relative frequencies distributed in six genera. The distribution by sectors together with the absolute and relative frequencies is showed in table 1.

In Red room, 164 fungal CFUs were observed contemplate taxa with their absolute frequency: Aspergillus fumigatus Fresen (03), Aspergillus oryzae (Ahlburg) Cohn (87), Aspergillus niger (48), Curvularia brachyspora Boedijn (01), Geotrichum candidum Link (02), Ochroconis mirabilis Samerp \& de Hoog (01), and Rhizopus oryzae Whet \& Prins (22). In Adult ICU, 48 CFUs were found: A. oryzae (12), Aspergillus niger (27), G. candidum (02), Penicillium citrinum Thom (02), R. oryzae (05). In Neonatal ICU, there were 10 CFUs: Aspergillus niger (05), G. candidum (02), $P$. citrinum (01) and $R$. oryzae (02).

The number of CFUs varied between the collects, as well as the occurrence of the taxa in relation to the sectors. Aspergillus fumigatus, $C$. brachyspora and $O$. mirabilis occurred from the second collect of Red room, Aspergillus niger occurred in the first and third collect in all sectors. Some taxa were isolated from all sectors but restricted to a single collect, such as $A$. oryzae, G. candidum and $R$. oryzae. Penicillium citrinum occurred in adult ICU and neonatal ICU in different collections (Table 1).

The high number of CFUs (222) occurring in the present work related to the number of taxa identified (08) is similar to the study by Silva et al. ${ }^{24}$, when checking the mycobiota of five sectors of two Clinical Analysis Laboratories in Pernambuco, Brazil, reported 140 fungal colonies, and of these, only four taxa. Similar results were also obtained by
Silva et al. $^{25}$ reporting 164 CFUs and identifying five representatives of filamentous fungi in the air analysis of a hospital in Paraíba, Brazil. Comparing with the literature a greater number of species identified occurs in studies where air is studied from open sites ${ }^{26,27}$.

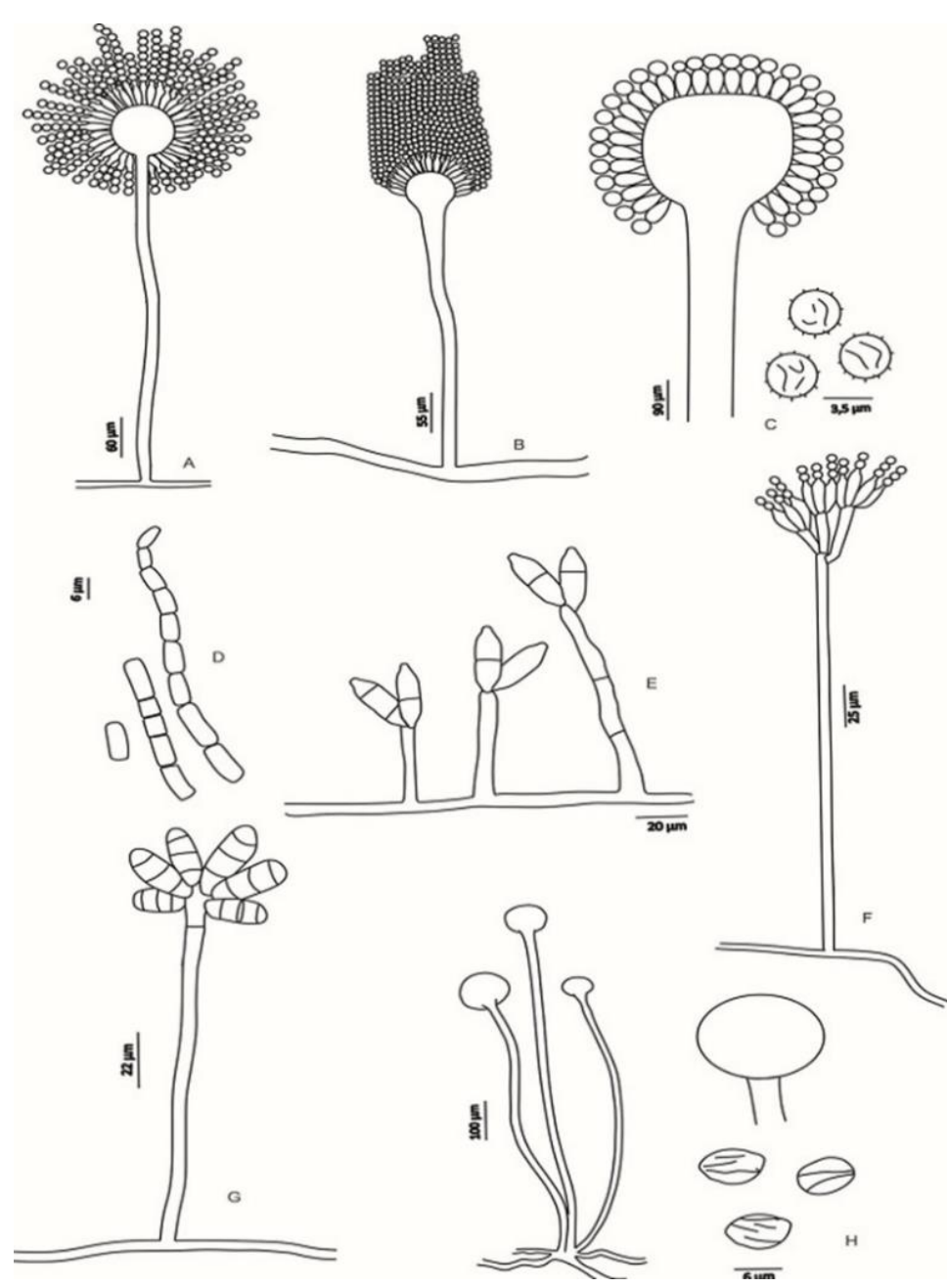

Figure 1. Anemophilous Fungi ocorrentes in a public hospital in Parnaíba, Piauí. A. Aspergillus oryzae B. Aspergillus fumigatus C. Aspergillus niger D. Geotrichum candidum E. Ochroconis mirabilis F. Penicillium citrinum G. Curvularia brachyspora H. Rhizopus oryzae. Drawings: CRUZ, M.O

Among the identified fungi, seven are included in the fungal group Deuteromycota and only one in Zygomycota. These results are quite frequent in analyzes of anemophilous fungi in closed environments, since representatives of the Zygomycota group, such as the genus Rhizopus, are more present in environments with high airflow ${ }^{26}$. Aspergillus and Penicillium are the most frequently mentioned in studies of fungal anemophilous, with Aspergillus being the most outstanding ${ }^{27,28,29}$. In the work of Silva et al. ${ }^{25}$, two species of Aspergillus were identified, Aspergillus niger and Aspergillus flavus, being similar to our study, with Aspergillus niger being the most frequent. Lacaz ${ }^{19}$ states that air is important in the dispersal 
of Aspergillus propagules, in addition explains that the suspension of these fungal propagules in the air occurs because of their small conidia.

Table 1. Distribution of taxa in relation to sector and collect. $\mathrm{AF}=$ absolute frequency; RF = Relative Frequency.

\begin{tabular}{|c|c|c|c|c|c|c|c|c|c|c|c|}
\hline \multirow[t]{3}{*}{ Taxa } & \multicolumn{9}{|c|}{ Sectors / collections } & \multirow[t]{3}{*}{$\overline{A F}$} & \multirow[t]{3}{*}{$\mathbf{R F}$} \\
\hline & \multicolumn{3}{|c|}{ Red room } & \multicolumn{3}{|c|}{ Adult ICU } & \multicolumn{3}{|c|}{ Neonatal ICU } & & \\
\hline & $1^{a}$ & $2^{\mathrm{a}}$ & 3 & $1^{\mathrm{a}}$ & $2^{\mathrm{a}}$ & $3^{a}$ & $1^{a}$ & $2^{\mathrm{a}}$ & $3^{a}$ & & \\
\hline $\begin{array}{l}\text { Aspergillus } \\
\text { fumigatus }\end{array}$ & - & 03 & - & - & - & - & - & - & - & 03 & $1 \%$ \\
\hline $\begin{array}{c}\text { Aspergillus } \\
\text { oryzae }\end{array}$ & - & - & 87 & - & - & 12 & - & - & - & 99 & $45 \%$ \\
\hline Aspergillus niger & 03 & - & 45 & 02 & - & 25 & 02 & - & 03 & 80 & $36 \%$ \\
\hline $\begin{array}{c}\text { Curvularia } \\
\text { brachyspora }\end{array}$ & - & 01 & - & - & - & - & - & - & - & 01 & $\begin{array}{c}0,5 \\
\%\end{array}$ \\
\hline $\begin{array}{l}\text { Geotrichum } \\
\text { candidum }\end{array}$ & - & 02 & - & - & 02 & - & - & 02 & - & 06 & $3 \%$ \\
\hline $\begin{array}{c}\text { Ochroconis } \\
\text { mirabilis }\end{array}$ & - & 01 & - & - & - & - & - & - & - & 01 & $\begin{array}{l}0,5 \\
\%\end{array}$ \\
\hline $\begin{array}{l}\text { Penicillium } \\
\text { citrinum }\end{array}$ & - & - & - & 01 & - & 01 & 01 & - & - & 03 & $1 \%$ \\
\hline Rhizopus oryzae & - & - & 22 & - & - & 05 & - & - & 02 & 29 & $13 \%$ \\
\hline
\end{tabular}

Mobin and Solmito ${ }^{30}$, analyzing the fungal microbiota of air conditioners in the intensive care units of Teresina, Piauí, obtained results similar to ours, and Aspergillus as the genus with the highest number of representatives and also identifying Aspergillus niger, A fumigatus and $P$. citrinum. In research by Furtado and Ferraroni $\mathrm{i}^{31}$ in hospitals in the city of Manaus, the genus Aspergillus, Penicillium and Rhizopus were also mentioned. As in the present study, Silva ${ }^{32}$ isolated in a hospital of Belo Horizonte, Minas Gerais, representatives of Aspergillus, Curvularia and Penicillium. Similar results were obtained by Flores and Onofre ${ }^{33}$ isolating Aspergillus, Penicillium and Geotrichum taxa from health units in Paraná. Menezes et al. ${ }^{26}$ in isolating anemophilous fungi from the city of Fortaleza, Ceará, identified all genera reported in this research, except Ochroconis, these researches corroborates the work presented here. Oliveira et al. ${ }^{17}$, isolared and identificared, through macro and micromorphological characteristics, pathogenic fungi in two particular hospital in Brazil reporting three genera of filamentous fungi: Aspergilllus, Penicillium and Fusarium.

The genus Aspergillus composes a group of fungi with great medical importance, because many of this species have pathogenic and toxic activity to animals and humans ${ }^{2}$. For Mezzari et al. ${ }^{34}$, exposure to spores of this kind is an alert to patients with allergy to these organisms. Aspergillus oryzae, a species of higher relative frequency in this research, is a fungus widely used in biotechnology and has already been isolated from air, soil, water and plant material. The toxins production by this microorganism depends heavily on the environment, thus being considered safe for industrial purposes and there is no report of diseases provided by it ${ }^{35}$.

Therefore, Aspergillus niger, second highest relative frequency taxa in this study, has been isolated from several environments, mainly air $36,30,24$. Some species of the Aspergillus niger group are large producers of ochratoxin A, a potent mycotoxin ${ }^{36}$. Pulmonary biopsy and human sputum analysis have shown the relationship of these organisms with respiratory diseases ${ }^{14}$. Aspergillus fumigatus is a major etiological agent of fungal infections as well as causing pulmonary fungal ball ${ }^{37}$. For years, this fungus was considered a weak pathogen, even causing aspergilloma and aspergillosis, however, with the increase in the number of patients with fragile immune system there was a great increase in the number of invasive aspergillosis caused by this fungus 38 .

Rhizopus oryzae, a specie of the Zygomycetes group, highlight by presenting third largest relative frequency in our analysis has been reported as etiological agent of mucormycosis, infection caused by fungi of the Mucorales order $^{37}$. Filho et al. ${ }^{39}$ reported a case of subcutaneous mucormycosis in the State of Paraná and isolated R. oryzae from the hospital environment where the patient was hospitalized, thus suggesting a nosocomial infection caused by contact with their spores.

About the other fungi shown in this analysis, and had a lower relative frequency, Geotrichum candidum is rare but large fungi causing infections. It has been isolated from human material, being an etiological agent of diseases related to the intestinal tract and to the respiratory system, as well as to the respiratory system, invasive skin infection. The major pathogenic potential of this fungus is based on its arthroconidia ${ }^{40,41}$. Penicillium citrinum products mycotoxins 42 and has long been reported as the etiologic agent of respiratory system diseases. Mok et al. ${ }^{43}$ reported a fatal case of pneumonia caused by $P$. citrinum in a person with leukemia. Ochroconis mirabilis and Curvularia brachyspora have been reported with a fungal pathogen that causes infection in immunocompetent patients ${ }^{44,45}$.

\section{CONCLUSION}

Eight fungal taxa with pathogenic historic were reported in a hospital in the city of Parnaíba, Piauí, Brazil. This study shows the importance of microbiological analysis in intensive care sectors in order to avoid nosocomial infections. Results showed in this paper are corroborated with works carried out in other cities in Brazil. The present study was a pioneer in the North of Piauí, thus contributing to the knowledge and dissemination of anemophilic fungal diversity in a hospital setting and indicating as alert for the technical staff involved with the patient and especially for the patients.

\section{ACKNOWLEDGMENTS}

The authors thanks Federal University of Piauí and the Dirceu Arcoverde-HEDA hospital, in specially the director general of the hospital, Adrizia Fontenele Carvalho da Silva and the director of the academic coordination, Patrícia Linhares de Castro, for the authorization and collaboration to develop this research. The second author also thanks Conselho Nacional de Desenvolvimento Científico (CNPq) for scholarship of Scientific Iniciation. 


\section{CONFLICT OF INTERESTS}

The authors declare no conflict of interes.

\section{REFERENCES}

1. Deacon J. Fungal Biology. 4 ed. Cornwall: Wiley-Blackwell, 2005.

2. Trabulsi LR, Alterthun, F. Microbiologia. 5 ed. São Paulo: Atheneu, 2008.

3. Hanski L, Von Hertzen L, Fyhrquist N, Koskinen K, Torppa K, Laatikainen T, Karisola P, Auvinen P, Paulin L, Mäkelä MJ, Vartiainen E, Kosunen TU, Alenius $H$, Haahtela T. Environmental biodiversity, human microbiota, and allergy are interrelated. Proceedings of the Natiotal Academy of Sciences. 2012;109(21):8334-8339.

4. Bongomin F, Gago S, Oladele RO, Denning DW. Global and MultiNational Prevalence of Fungal Diseases-Estimate Precision. Journal of Fungi. 2017;3(4):1-29.

5. Zhang D, Murata K, Hu W, Yuan H, Li W, Matsusaki H, Kakikawa M. Concentration and viability of bacterial aerosols associated with weather in asia continental outflow: current understanding. Aerosol Science and Engineering. 2017;1(66):66-77.

6. Liu H, Hu Z, Zhou M, Hu J, Yao X, Zhang H, Li Z, Lou L, Xi C, Qian H, Li $C, X u X$, Zheng $P, H u B$. The distribution variance of airborne microrganisms in urban and rural environments. Environmental Pollution. 2019;247:898-906.

7. Temperini CV, Franchi ML, Rozo MEB, Greco M, Pardo AG, Pose GN. Diversity and abundance of airbone fungal spores in a rural cold dry desert environment in Argentinean Patagonia. Science of the Total Environment. 2019;665:513-520.

8. Tanaka D, Sato K, Goto M, Fujiyoshi S, Maruyama F, Takato S, Shimada T. Sakatoku A, Aoki K, Nakamura S.Airborne microbial communities at high-altitude and suburban sites in Toyama, Japan suggest a new perspective for bioprospecting. Fronties Bioengineeing Biotechnology. 2019;7(12):1-11.

9. Lobato CR, Vargas VS, Silveira ES. Sazonalidade e prevalência de fungos anemófilos em ambiente Hospitalar no Sul do Rio Grande do Sul. Revista da Faculdade de Ciências Médicas. 2009:11:2: 21-28.

10. Madhwal S, Prabu V, Sundriyal S, Shridhar V. Ambient bioaerosol distribution and associated health risks at a high traffic density junction at Dehradun city, India. Environmental Monitoring and Assessment. 2020; 192-196.

11. Grumach AS. Alergia e imunologia na infância e na adolescência. São Paulo: Atheneu, 2008.

12. Souza AEF, Vieira KVM, Gomes LFAV. Isolamento e identificação da microbiota fúngica anemófila em diversos setores do Centro de Ciências Biológicas e da Saúde da Universidade Estadual da Paraíba. Revista de Biologia e Farmácia. 2008;2(2):31-49.

13. Lanzerstorfer $A$, Hackl $M$, Schlömer $M$, Rest B, Deutsch-Grasl E, Lanzerstorfer $C$. The influence of air-dispersed essential oils from lemon (Citrus limon) and silver fir (Abies alba) on airborne bacteria and fungi in hospital rooms. Journal of Environmental Science and Health. 2019; Parte A: $1-5$.

14. Gniadek A, Macura AB, Górkiewicz M. Cytotoxicity of Aspergillus fungi isolated from hospital environment. Polish Journal of Microbiology. 2011:60(1):59-63.

15. Verde CS, Almeida SM, Matos J, Guerreiro D, Meneses M, Faria T, Botelho D, Santos M, Viegas C. Microbiological assessment of indoor air quality at diferente hospital sites. Research Microbiology. 2015;166(7):557-563

16. Khan HÁ, Baig FK, Mehboob R. Nosocomial infeccions: Epidemioloy, prevention, control and survellance. Asian Pacific Journal of Tropical Biomedicine. 2017;7(5): 478-482.

17. Oliveira MT, Batista NKR, Gil ES, Silva MRRS, Costa CR, Bara MTF Torres IMS. Risks associated with pathogenic fungi isolated from surgical centers, intensive care units, and materials sterilization center in hospitals. Risks associated with pathogenic fungi isolated from critical hospital areas. Medical Mycology. 2020; 0(0): 1-6.

18. Martin JP. Use of acid, rose bengal, and streptomycin in the plate method for estimating soil fungi. Soil Science. 1950;69(3):215-232.

19. Lacaz CL. Guia para identificação: fungos, actinomicetos e algas de interesse médico. São Paulo: Sarvier, 1998.

20. Riddel RW. Permanent stained mycological preparations obtained by slide culture. Mycologia. 1950;42:265-270.

21. Ellis MB. Dematiaceous Hyphomycetes. Surrey: Common- Wealth Mycological Institute, 1971.
22. Klich MA, Pitt Jl. A laboratory guide to common Aspergillus species and their teleomorphs. North Ryde: Csiro, 1988.

23. Shi D, Lu G, Mei H, Hoog GS, Samerpitak K, Deng S, Shen Y, Liu W. Subcutaneous infection by Ochroconis mirabilis in an immunocompentent patient. Medical Mycologia Case Report. 2016;11:44-47.

24. Silva WLS, Silva ASV Carvalho PL, Farias TS, Carvalho MFFP. Isolamento e identificação de fungos anemófilos em laboratórios de rede privada na cidade de Salgueiro - PE. Revista de Biologia e Farmácia. 2011a; 6(1):129-135.

25. Silva ASV Isolamento e identificação de fungos anemófilos em um hospital de rede pública do sertão da Paraíba. Revista de Biologia e Farmácia. 2011b;6(2):114-120.

26. Menezes EA, Carvalho PG, Trindade ECPM, Sobrinho GM, Cunha FA, Castro FFM. Airborne fungi causing respiratory allergy in patients from Fortaleza, Ceará, Brazil. Jornal Brasileiro de Patologia e Medicina Laboratorial. 2004;40(2): 79-84.

27. Rêgo CM, Santos FS. Ocorrência de fungos anemófilos e sua relação com fatores abióticos em Barreiras, Bahia. Revista Brasileira de Biociência. 2015;13(4):265- 271.

28. Rosa H, Lemos JA, Costa CR, Silva MRR, Fernandes OFL. Ocorrência de fungos filamentos em acervo da Faculdade de Medicina da Universidade Federal de Goiás. Revista de Patologia Tropical. 2008; 37(3):65-69.

29. Pereira BFP, Melo LE, Costa PF. Fungos anemófilos isolados na cidade de Belém, Estado do Pará - Brasil. Revista Eletrônica de Biologia. 2013;6(1):82-93.

30. Mobin M, Solmito MA. Microbiota fúngica dos condicionadores de ar nas unidades de terapia intensiva de Teresina, Pl. Revista da Sociedade Brasileira de Medicina Tropical. 2006;39(6): 556-559.

31. Furtado MSS, Ferraroni JJ. Fungos anemófilos em ambientes hospitalares da cidade de Manaus. Ciência e Cultura. 1981;4:42-47.

32. Silva MG. Flora fúngica do ar e do piso no Hospital das Clínicas da UFMG, Belo Horizonte, Brasil. Revista de Microbiologia. 1983;14(3):215-522.

33. Flores $L H$, Onofre SB. Determinação da presença de fungos anemófilos e leveduras em unidade de saúde da cidade de Francisco Beltrão - PR. Revista de Saúde e Biologia. 2010;5(2):22-26. 2010.

34. Mezzari A, Perin C Júnior SAS, Bernd LAG, Gesu DD. Os fungos anemófilos e sensibilização em indivíduos atópicos em Porto Alegre. RS. Revista da Associação Médica Brasileira. 2003;49(3):30-46.

35. Blumenthal CZ. Production of toxic metabolites in Aspergillus niger, Aspergillus oryzae, and Trichoderma reesei: justification of mycotoxin testing in food grade enzyme preparations derived from the three fungi. Regulatory Toxicology and Pharmacology. 2004;39(2):214-228.

36. Pitt Jl. Integration of modern taxonomic methods for Penicillium and Aspergillus classification. 1 ed. London: Academic, 2000.

37. Lacaz CS, Porto E, Martins JEC, Heins-Vaccari EM, Takahashi MN. Tratado de Micologia Médica. 9. ed. São Paulo, Sarvier, 2002. 1104p.

38. Latgé JP. Aspergillus fumigatus and aspergillosis. Clinical Microbiology Reviews. 1999;12 (2):310-350.

39. Filho FQT, Coelho A, Porto E, Lameira RF, Freitas MM, Barboza J, Ramos $J L Z$. Subcutaneus mucormycosis caused by Rhizopus oryzae probable nosocomial acquired infeccion. Revista Institucional de Medicina Tropical. 1985;27(4):201-206.

40. Sfakianakis A, Krasagakis K, Stefanidou M, Maraki S, Koutsopoulos A, Kofteridis $D$, Samonis $G$, Tosca $A$. Invasive cutaneous infection with Geotrichum candidum - sequential treatment with amphotericin $B$ and voriconazole. Medical Mycology. 2007;45(1):81-84

41. Graeff $L D$, Seidel $D$, Vehreschild MJ, Hamprecht $A$, Kindo A, Racil Z, Demeter J, De Hoog S, Aurbach U, Ziegler M, Wisplinghoff H, Cornely $O A$. Invasive infections due to Saprochaete and Geotrichum species: Report of 23 cases from the Fungi Scope Registry. Mycosis. 2017; 60(4):273-279.

42. Schmidt-heydt $M$, Stoll $D$, Geisena $R$. Whole-genome sequencing of the fungus Penicillium citrinum reveals the biosynthesis gene cluster for the mycotoxin citrinin. Microbiology Resource Announcements. 2019; 8(4):12.

43. Mok T, Koehler A P, Yu MY, Ellis DH, Johnson PJ, Wickham NWR. Fatal Penicillium citrinum pneumonia with pericarditis in a patient with acute leucemia. Journal of Clinical Microbiology. 1997:35(10):2654 - 2656.

44. Shi D, Lu G, Mei H, Hoog GS, Samerpitak K, Deng S, Shen Y, Liu W. Subcutaneous infection by Ochroconis mirabilis in an immunocompentent patient. Medical Mycologia Case Report. 2016;11:44-47.

45. Kiss N, Homa M, Manikandam P, Mythili A, Krizsán K, Revathi R, Varga M, Papp T, Vágvölgyi C, Kredics L, Kocsubé S. New Species of the Genus Curvularia: C. tamilnaduensis and C. coimbatorensis from Fungal Keratitis Cases in South India. Pathogens. 2020; 9(9):1-1 